\title{
ESTABELECIMENTO IN VITRO DE ESTRELÍCIA (Strelitzia reginae Banks.)
}

\author{
In vitro stablisment of strelitzia (Strelitzia reginae Banks.)
}

\author{
Patrícia Duarte de Oliveira Paiva ${ }^{1}$, Renato Paiva ${ }^{2}$, Moacir Pasqual ${ }^{1}$, Luciano Vilela Paiva ${ }^{3}$
}

\begin{abstract}
RESUMO
A estrelícia (Strelitzia reginae Banks.) é uma planta ornamental tropical de grande valor comercial. O seu desenvolvimento, no entanto, é bastante lento e, conseqüentemente, a produção de novas mudas também. Assim, a cultura de tecidos é uma alternativa para a formação de novas mudas. Objetivou-se, assim, avaliar o comportamento in vitro, de estrelícia e a viabilidade de propagação dessa espécie por meio desse processo. Para o estabelecimento in vitro utilizaram-se como explantes gemas axilares, segmentos foliares e embriões imaturos, não se obtendo sucesso nos dois primeiros. No cultivo dos embriões, avaliaram-se o período para coleta das sementes e o desenvolvimento dos embriões em diferentes concentrações de sacarose e do meio de cultura e ainda o uso de diferentes concentrações de BAP. Determinou-se como melhor período para coleta das sementes e extração dos embriões 20 semanas após a polinização. As diferentes concentrações do meio MS não alteraram o desenvolvimento dos embriões, sendo esse favorecido pela adição de 20,64 g/L de sacarose ao meio de cultura. A adição de BAP proporcionou a formação de plantas de menor tamanho.
\end{abstract}

Termos para indexação: Estrelícia, micropropagação, Strelitzia reginae, cultura de embriões.

\section{SUMMARY}

Strelitzia (Strelitzia reginae Banks.) is a tropical ornamental plant of expressive commercial value. Its development however is slow and the production of seedlings is reduced. Thus the use of tissue culture is an alternative for its propagation. The objective of this work was to evaluate the in vitro behavior of this specie as well as the viability of the in vitro propagation technique. For the in vitro establishment, leaf segments, axillaries buds, and immature embryos were used as explants. No in vitro development was observed using leaf segments and axillaries buds as explants. The period of seed harvest and embryo development in different sucrose concentrations and culture medium and the use of different concentrations of BAP were evaluated during embryo culture. The best period for seed harvest and embryo extraction was observed to be 20 weeks after pollination. Variations in the MS medium concentrations have no effect on embryo development. Higher shoot development can be obtained using MS medium supplemented with 20.64 g/L sucrose. The addition of BAP produced plants with reduced size.

Index terms: Strelitzia, micropropagation, Strelitzia reginae, embryo culture.

(Recebido para publicação em 24 de abril de 2003 e aprovado em 18 de agosto de 2004)

\section{INTRODUÇÃO}

A estrelícia (Strelitzia reginae Banks.) é uma planta ornamental de expressivo valor comercial. Essa planta, no entanto, apresenta lento desenvolvimento, demandando de 5 a 6 anos para iniciar a produção de flores. A propagação convencional pode ser realizada pela divisão de touceiras, resultando em pequeno número de mudas ou por sementes, as quais apresentam dormência e possuem lenta germinação.

Os primeiros testes para micropropagação de estrelícia foram realizados por Ziv e Halevy (1983), os quais obtiveram plantas a partir de gemas axilares. Esse, no entanto, é um método destrutivo, havendo a necessidade de destruição das mudas, as quais produzem individualmente entre 5 a 10 gemas. A utilização de embriões e folhas jovens como explantes são métodos que e- vitam a destruição de matrizes e podem ser bastante eficientes para a micropropagação de plantas (PIERIK, 1987).

Os embriões geralmente são coletados em estágio imaturo e inoculados in vitro em meios de cultura contendo sacarose e, em geral, em concentrações mais elevadas (COLLINS e GROSSER, 1984; HU e WANG, 1986; GEORGE, 1996a). A exigência em sacarose é variada em razão do estágio de maturação dos embriões, sendo os imaturos mais exigentes (HU e FERREIRA, 1990). A concentração dos sais do meio de cultura bem como variações no tipo e concentrações de reguladores de crescimento também podem alterar o desenvolvimento dos embriões cultivados in vitro (COLLINS e GROSSER, 1984; PIERIK, 1987; GEORGE, 1996a,b).

\footnotetext{
1. Professora do Departamento de Agricultura, Universidade Federal de Lavras/UFLA - Caixa Postal 3037 - $37200-000$ - Lavras, MG, pdolivei@ufla.br

2. Professor do Departamento de Biologia/UFLA.

3. Professor do Departamento de Química/UFLA.
} 
Objetivou-se neste trabalho estabelecer a estrelícia in vitro utilizando diferentes tipos de explantes.

\section{MATERIAL E MÉTODOS}

Os explantes foram retirados de plantas adultas de estrelícia (Strelitzia reginae Banks.) ocorrentes no Viveiro de Plantas Ornamentais da Universidade Federal de Lavras, Lavras-MG, e o procedimento de desinfestação e os tratamentos testados variaram em função dos diferentes tipos de explantes.

\section{Segmentos foliares}

Folhas jovens foram extraídas das plantas, imersas em água destilada e transportadas para o Laboratório de Cultura de Tecidos do Departamento de Agricultura. As folhas foram desinfestadas em solução de hipoclorito de sódio a $30 \%$, acrescido de 1,0 $\mathrm{g} / \mathrm{L}$ de Benomyl e 52,0 mg/L de cloranfenicol, por 20 minutos. Em câmara asséptica, foram lavadas por quatro vezes em água destilada autoclavada e mantidas em solução contendo 1,0 g/L de PVP. Seccionaram-se as folhas em segmentos de tamanhos diferenciados $(1 \mathrm{x} 1 \mathrm{~cm} ; 2 \mathrm{x} 1 \mathrm{~cm})$ e inoculadas em diferentes posições (vertical, horizontal, inclinado) nos meios de cultura.

Nos experimentos para testar o efeito de diferentes produtos sobre o desenvolvimento de segmentos foliares, avaliou-se o efeito de concentrações de PVP, carvão ativado, cloranfenicol, benomyl e 2,4-D (Ácido 2,4 diclorofenoxiacético) acrescidos ao meio de cultura MS (MURASHIGE e SKOOG, 1962) em diferentes combinações, nos seguintes tratamentos: meio MS; MS + 4 mg/L 2,4-D; MS + 52 mg/L de cloranfenicol; MS + $4 \mathrm{mg} / \mathrm{L}$ 2,4-D + $52 \mathrm{mg} / \mathrm{L}$ de cloranfenicol; MS + 2 g/L de carvão ativado + $52 \mathrm{mg} / \mathrm{L}$ de cloranfenicol; MS + 160 mg/L PVP (PVP 40, Sigma) + $52 \mathrm{mg} / \mathrm{L}$ de cloranfenicol; $\mathrm{MS}+800 \mathrm{mg} / \mathrm{L} \mathrm{PVP} \mathrm{+}$ $52 \mathrm{mg} / \mathrm{L}$ de cloranfenicol; MS + $800 \mathrm{mg} / \mathrm{L} \mathrm{PVP}+1$ g/L Benomyl; MS + 2 g/L de carvão ativado +1 g/L Benomyl; MS $+800 \mathrm{mg} / \mathrm{L}$ PVP $+52 \mathrm{mg} / \mathrm{L}$ de cloranfenicol $+1 \mathrm{~g} / \mathrm{L}$ Benomyl ; MS $+2 \mathrm{~g} / \mathrm{L}$ de carvão ativado + $52 \mathrm{mg} / \mathrm{L}$ de cloranfenicol + $1 \mathrm{~g} / \mathrm{L}$ Benomyl.

Os segmentos foliares foram também inoculados no meio recomendado por Ziv e Halevy (1983), composto de meio MS acrescido de $52 \mathrm{mg} / \mathrm{L}$ de cloranfenicol, $25 \mathrm{mg} / \mathrm{L}$ de oxitetraciclina, $10 \mathrm{~g} / \mathrm{L}$ de carvão ativado, 2,5 mg/L de AIB (Ácido Indol Butírico), $1 \mathrm{mg} / \mathrm{L}$ de ANA (Ácido naftaleno acético), $5 \mathrm{mg} / \mathrm{L}$ de cinetina, $0,5 \mathrm{mg} / \mathrm{L}$ de 2,4-D, $30 \mathrm{~g} / \mathrm{L}$ de sacarose e 7 g/L de agar (Merck); e também em meio B5
(GEORGE, 1996a) acrescido de $400 \mathrm{mg} / \mathrm{L}$ PVP ou 1 g/L de carvão ativado. Os explantes foram mantidos com temperatura $26^{\circ} \mathrm{C}$, no escuro, por 30 dias, e 45 dias em fotoperíodo de 16 horas de luz,irradiância de $43 \mu \mathrm{mol} \mathrm{m} \mathrm{s}^{-1}$.

\section{Gemas axilares}

Para micropropagação de gemas axilares, utilizou-se a metodologia descrita por Ziv e Halevy (1983). Os segmentos contendo as gemas foram mantidos por 24 horas em solução de antioxidantes constituída de $50 \%$ dos sais do meio MS, excluindo-se as vitaminas e sacarose, sem solidificante e acrescido de 150 mg/L de ácido cítrico, 100 mg/L de ácido ascórbico, $25 \mathrm{mg} / \mathrm{L}$ de benomyl, $5 \mathrm{mg} / \mathrm{L}$ de cloranfenicol e $5 \mathrm{mg} / \mathrm{L}$ de oxitetraciclina, $\mathrm{pH} 4,5$. Os explantes foram mantidos nessa solução por 24 horas, no escuro, a $26^{\circ} \mathrm{C}$. Extraíram-se as gemas e inocularam-se em meio MS, acrescido de $10 \mathrm{~g} / \mathrm{L}$ de carvão ativado, 52 $\mathrm{mg} / \mathrm{L}$ de cloranfenicol, $2,5 \mathrm{mg} / \mathrm{L}$ de AIB, $1 \mathrm{mg} / \mathrm{L}$ ANA, $5 \mathrm{mg} / \mathrm{L}$ cinetina, $0,5 \mathrm{mg} / \mathrm{L}$ de 2,4-D e $7 \mathrm{~g} / \mathrm{L}$ ágar. Os explantes foram mantidos por 10 dias, no escuro, à temperatura de $26^{\circ} \mathrm{C}$. Após, foram transferidos para fotoperíodo de 16 horas de luz. Testou-se também o efeito da adição $400 \mathrm{mg} / \mathrm{L}$ de PVP em substituição ao carvão ativado.

\section{Embriões}

Os frutos foram coletados no campo e levados para o laboratório, onde foram abertos, retirando-se as sementes. Em seguida, essas foram desinfestadas em solução de hipoclorito de sódio a $30 \%$ por 15 minutos, sendo, em seguida, em câmara de fluxo laminar, lavadas 4 (quatro) vezes em água destilada autoclavada extraindo-se os embriões e inoculando-se no meio de cultura com os tratamentos. O material foi mantido em sala de crescimento com temperatura de $26 \pm 1^{\circ} \mathrm{C}$ e 16 horas de luz e irradiância de $43 \mu \mathrm{mol}$ $\mathrm{m}^{-2} \mathrm{~s}^{-1}$.

Os embriões foram dispostos em experimentos com diferentes tratamentos, com o objetivo de avaliar o seu desenvolvimento. Os frutos foram coletados com 4, 8, 16 e 20 semanas após a polinização, com objetivo de se avaliar o melhor período para extração dos embriões. No primeiro experimento, testaram-se as concentrações de sacarose: $0 ; 7,5 ; 15 ; 30 ; 45$ e 60 $\mathrm{g} / \mathrm{L}$ acrescidas ao meio MS, solidificado com $7 \mathrm{~g} / \mathrm{L}$ de ágar. Em outro experimento, avaliaram-se as concentrações de sais do meio MS: 12,5; 25; 50; 75; 100 e $125 \%$. As concentrações de mio-inositol, vitaminas 
e glicina foram mantidas sem alteração. A sacarose, neste experimento, foi utilizada na concentração de $30 \mathrm{~g} / \mathrm{L}$. O efeito de dosagens de BAP (0-controle; 0,$5 ; 1,0 ; 2,0 ; 4,0$ e $8,0 \mathrm{mg} / \mathrm{L}$ ) acrescidas ao meio MS também foi avaliado.

\section{RESULTADOS E DISCUSSÃO}

Não foi observada morfogênese ou calogênese quando se utilizaram gemas axilares ou segmentos foliares, independente do tratamento aplicado. Observaram-se em todo o material inoculado intensa oxidação e contaminação em todos os explantes. Assim, não foi possível reproduzir o protocolo desenvolvido por Ziv e Halevy (1983) para a propagação in vitro de estrelícia por meio de gemas axilares.

Dos frutos coletados para extração dos embriões, observou-se que esses apresentaram em média 41,87 sementes. As características morfológicas das sementes em função das diferentes idades de coleta encontram-se na Tabela 1.

Embriões extraídos 20 semanas após a polinização originaram plantas completas e bem formadas. No entanto, quando retirados em período inferior a 20 semanas, independentemente dos tratamentos aplicados, formaram calos ou estruturas semelhantes a embrióides. Deste material, não foi possível regenerar plantas, apesar de várias tentativas com transferências para meios com várias combinações de reguladores de crescimento.
A interação entre as diferentes idades dos embriões e as concentrações do meio MS apresentou significância apenas para a análise de oxidação, não influenciando, no entanto, a altura dos brotos ou a formação de raízes. Esses parâmetros e também a ocorrência de oxidação foram significativamente influenciados pelas concentrações de sacarose utilizadas em combinação com as diferentes idades dos embriões. As diferentes concentrações do regulador de crescimento BAP, acrescidas ao meio de cultura, influenciaram apenas o tamanho dos brotos formados.

Diferentes concentrações do meio MS, independentemente das épocas de coleta das sementes, não influenciaram o desenvolvimento dos embriões. Assim, não foi possível determinar uma concentração ótima do meio MS para iniciação da cultura. Com esse resultado, infere-se que, possivelmente, todo o processo de germinação é promovido pelas reservas do cotilédone, independente do fornecimento externo. Por outro lado, o desenvolvimento dos embriões foi influenciado pelas diferentes idades em que foram coletados. A germinação nos embriões ocorreu apenas naqueles coletados com 20 semanas, como se visualiza na Figura 1. Embriões em estágios inferiores de maturidade não apresentaram formação de parte aérea e raízes; no entanto, os embriões coletados com 12 ou 16 semanas apresentaram entumescimento, formando uma estrutura sem forma definida, aparentando embrióides, mas não regeneraram plântulas. O tamanho médio dos brotos formados a partir de embriões de 20 semanas foi de $0,45 \mathrm{~cm}$, com amplitude entre 0,8 e 4,0 cm.

TABELA 1 - Características morfológicas observadas para as sementes de estrelícia em função da época de coleta.

\begin{tabular}{ccccc}
\hline Semanas & Arilo & Endosperma & Tegumento & Tamanho do Embrião \\
\hline 8 & Branco & Líquido & Claro & $2-3 \mathrm{~mm}$ \\
12 & Amarelo & Pastoso & Claro & $4-5 \mathrm{~mm}$ \\
16 & Amarelo escuro & Pastoso a rígido & Claro & $5-6 \mathrm{~mm}$ \\
20 & Laranja & Rígido & Marrom a cinza & $7-8 \mathrm{~mm}$ \\
$>20$ & Laranja & Rígido a seco & Cinza escuro a preto & $7-8 \mathrm{~mm}$ \\
\hline
\end{tabular}


Observou-se oxidação em embriões cultivados em todas as concentrações do meio MS, o que permite inferir que a intensidade de ocorrência de oxidação é inerente ao embrião e não conseqüência das concentrações utilizadas no meio de cultura.

A concentração ideal do meio MS no qual ocorreria menor oxidação para embriões com idade de 20 semanas é de 102,08\% do original. A ocorrência de oxidação tendeu a se elevar em concentrações do meio MS superiores a $100 \%$. A redução nas concentrações de sais do meio de cultura, conforme sugerido por Jarret et al. (1985), não demonstrou ser eficiente para controle de oxidação, ao contrário, oxidação em maior intensidade foi observada quando menores concentrações do meio MS foram utilizadas.

Observou-se a influência das concentrações de sacarose no desenvolvimento dos embriões em função de suas diferentes idades de coleta. A formação de parte aérea ocorreu apenas nos embriões coletados com 20 semanas (Figura 2), ocorrendo formação de brotos de tamanho médio $2,27 \mathrm{~cm}$, com amplitude de tamanhos variando de 0,5 a 5,7 cm. Raízes foram formadas apenas nos embriões que apresentavam parte aérea.

Com essas observações, pode-se inferir que o desenvolvimento dos embriões de estrelícia em estágios bastante imaturos não é unicamente dependente de fonte energética, mas de algum outro fator inerente aos embriões. Esse fator pode ser a presença de algum inibidor ou a imaturidade dos embriões. Assim, mesmo com estímulo externo, apenas o fornecimento de sais e sacarose não são suficientes para induzir a germinação. A recomendação de aumento das concentrações de sacarose para estimular a brotação em embriões imaturos, conforme sugerido por diversos autores (COLLINS e GROSSER, 1984; HU e WANG, 1986; PIERIK, 1987; SARAVITZ e RAPER JUNIOR, 1995; GEORGE, 1996a), não foi eficiente para essa espécie.

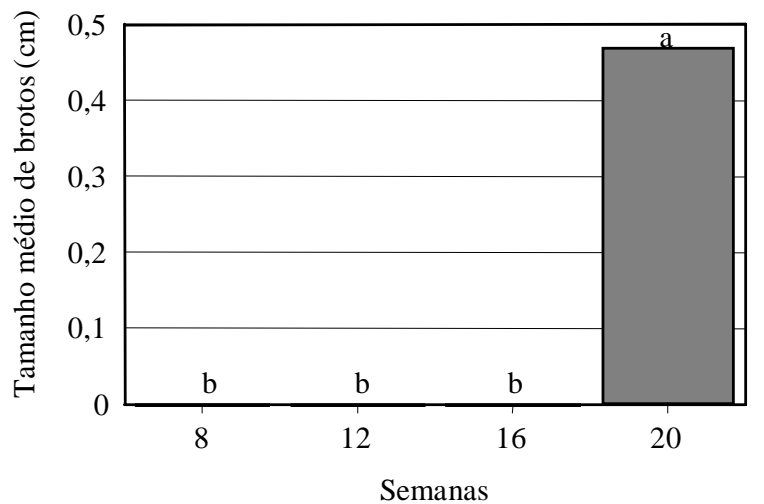

FIGURA 1 - Tamanho médio dos brotos formados em embriões de estrelícia cultivados in vitro (meio MS) em função das diferentes idades das sementes. Médias seguidas de mesma letra não diferem entre si pelo teste de Kruskal-Wallis ao nível de 5\%.

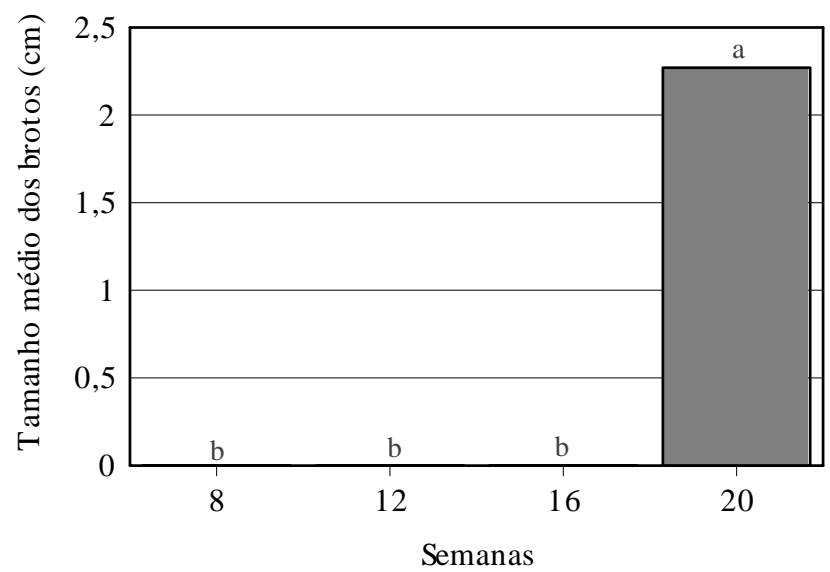

FIGURA 2 - Tamanho médio dos brotos formados em embriões de estrelícia cultivados in vitro (em diferentes concentrações de sacarose) em função das diferentes idades das sementes. Médias seguidas de mesma letra não diferem entre si pelo teste de Kruskal-Wallis ao nível de 5\%.

Ciênc. agrotec., Lavras, v. 28, n. 5, p. 1031-1037, set.out., 2004 
Os embriões com idade de 20 semanas não exigiram elevação da concentração de sacarose, ao contrário, melhor desenvolvimento de parte aérea foi obtido com a concentração de 20,64 g/L de sacarose (Figura 3), o que indica que esses já estejam atingindo o estágio autotrófico, conforme afirmação de Hu e Wang (1986) ou, caso não estejam nesse estágio, reforça-se a hipótese de que outro fator do embrião é responsável por estimular a germinação. Observou-se ainda que a ausência de sacarose no meio de cultura ou a utilização de concentração elevada (60 g/L) inibiu o desenvolvimento dos embriões.

O processo de oxidação ocorreu de forma mais intensa nos embriões de 20 semanas Embriões mais jovens, muitas vezes, não apresentavam nenhum desenvolvimento, permanecendo no meio da forma como foram inoculados, não apresentando também oxidação. Ao contrário, os embriões que apresentavam entumescimento ou formação de estrutura semelhante a calos liberaram exudatos no meio, demonstrando ser a oxidação consequiência do metabolismo.

Segundo George (1996b), explantes mais maduros são menos propícios à ocorrência de oxidação em relação aos jovens. O que se observou no cultivo de estrelícia foi uma tendência de as plantas que apresentaram menor desenvolvimento apresentarem oxidação mais intensa e os embriões muito jovens, quando não se desenvolveram, não apresentaram oxidação. Além disso, visualmente observou-se que aqueles embriões que brotaram mais rapidamente apresentavam menor intensidade de oxidação em relação aos que demoravam mais, mas após desenvolvidas as plantas, as diferentes intensidades de coloração do meio tenderam a se igualar. Observou-se neste trabalho que a intensidade de oxidação tendeu a aumentar à medida que se elevam as concentrações de sacarose, independente da idade dos embriões, concordando com os resultados observados por Cai e Butler (1990), os quais também observaram aumento na oxidação de sorgo em função da presença de maiores concentrações de sacarose.

O uso de BAP não estimulou a formação de maior número de brotos ou outras estruturas como embrióides. À medida que se aumentaram as dosagens do regulador, observou-se redução na altura dos brotos (Figura 4). Brotos de maiores tamanhos $(1,15$ e $1,22 \mathrm{~cm})$ foram obtidos, respectivamente, em meios acrescidos de $0,5 \mathrm{mg} / \mathrm{L}$ de $\mathrm{BAP}$ ou na ausência desse. A amplitude dos brotos formados variou de 1,0 a 2,5 cm, na ausência de BAP, e de 0,7 a $4,0 \mathrm{~cm}$, com $0,5 \mathrm{mg} / \mathrm{L}$ do regulador de crescimento. $\mathrm{O}$ desenvolvimento radicular ocorreu independente da presença de BAP no meio de cultura, não ocorrendo diferenças no comprimento de raízes em função das diferentes concentrações utilizadas. A ocorrência de oxidação também não foi afetada pela presença do regulador de crescimento no meio de cultura, diferindo dos resultados de Cai e Butler (1990), os quais observaram aumento de oxidação do meio devido à adição de regulador de crescimento.

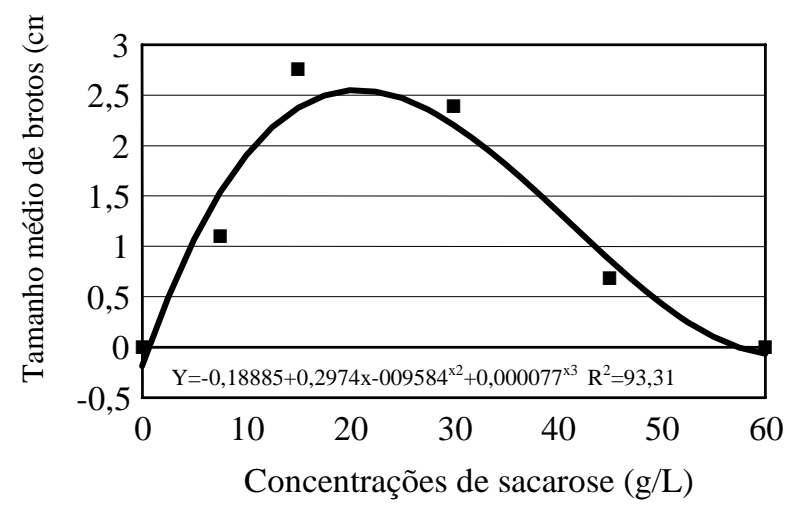

FIGURA 3 - Efeito de diferentes concentrações de sacarose sobre a formação de brotos em embriões de estrelícia coletados com a idade de 20 semanas. 


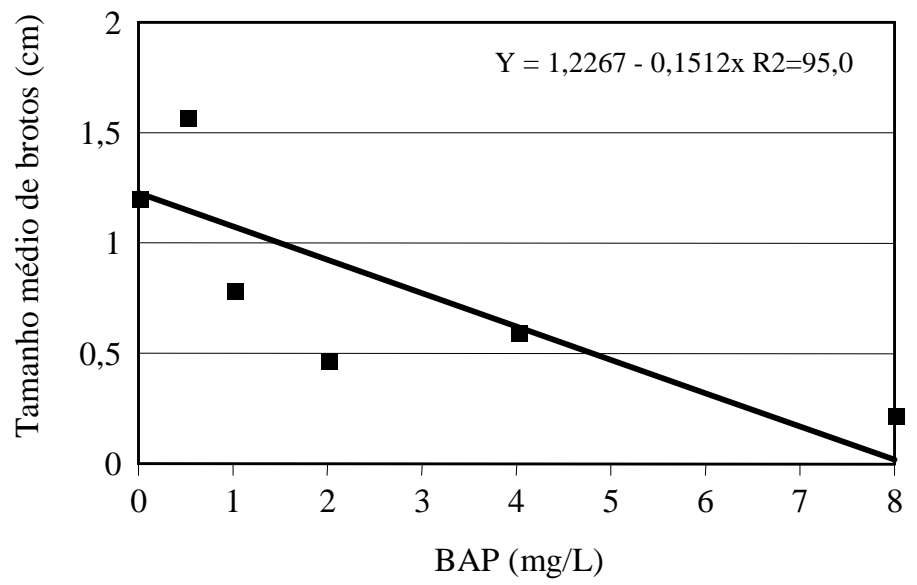

FIGURA 4 - Efeito do BAP sobre o tamanho médio de brotos formados em estrelícia, decorrente da germinação de embriões.

\section{CONCLUSÕES}

Nas condições em que os trabalhos foram realizados, conclui-se que:

a) Não foi possível propagar a estrelícia por meio de segmentos foliares ou gemas axilares, mas consegue-se o desenvolvimento in vitro de plantas completas utilizando como explantes embriões imaturos.

b) A idade ótima de coleta das sementes para extração dos embriões é de 20 semanas após a polinização. Embriões imaturos, com idade inferior a essa, não germinam, mesmo em presença de valores elevados de sacarose. O nível ótimo de sacarose para o desenvolvimento dos embriões de 20 semanas é de 20,64 g/L.

c) Variações na concentração do meio MS não alteram o desenvolvimento dos embriões.

d) Plantas de maior tamanho são formadas na sua ausência ou na concentração de 0,5 mg/L de BAP.

\section{REFERÊNCIAS BIBLIOGRÁFICAS}

CAI, T.; BUTLER, L. Plant regeneration from embryogenic callus initiated from immature inflorescences of several high-tannin sorghums. Plant Cell, Tissue and Organ Culture, Dordrecht, v. 20, p. 101-110, 1990.

COLLINS, G. B.; GROSSER, J. W. Culture of embryos. In: VASIL, I. K. Cell culture and somatic cell genetics of plants. Orlando: Academic, 1984. v. 1, p. 241-257.
GEORGE, E. F. Plant propagation by tissue culture: part 1: the technology. 2. ed. Edington: Exegetics, 1996a. 1574 p.

GEORGE, E. F. Plant propagation by tissue culture: part 2: in practice. 2. ed. Edington: Exegetics, 1996b. $1361 \mathrm{p}$.

HU, C.; WANG, P. Embryo culture: technique and application. In: EVANS, D. A.; SHARP, W. R.; AMMIRATO, P. V. Handbook of plant cell culture: technique and applications. New York: Macmillan, 1986. v. 4, p. 43-96.

HU, C. Y.; FERREIRA, A. G. Cultura de embriões. In: TORRES, A. C.; CALDAS, L. S. Técnicas e aplicações da cultura de tecidos de plantas. Brasília: EMBRAPA/CNPH-ABCTP, 1990. p. 71-86.

JARRET, R. L.; RODRIGUEZ, W.; FRENANDEZ, R. Evaluation, tissue culture propagation and dissemination of 'Saba' and 'Pelipita' plantains in Costa Rica. Scientia Horticulturae, Amsterdam, v. 25, p. 137-147, 1985.

MURASHIGE, T.; SKOOG, F. A revised medium for rapid growth and bioassays with tobacco tissue cultures. Physiologia Plantarum, Copenhagen, v. 15, p. 473497, 1962.

PIERIK, R. L. M. In vitro culture of higher plants. Dordrecht: Martinus Nyhoff, 1987. 344 p. 
SARAVITZ, C. H.; RAPER JUNIOR, C. D. Responses to sucrose and glutamine by soybean embryos grown in vitro. Physiologia Plantarum, Copenhagen, v. 93, p. 799-805, 1995.
ZIV, M.; HALEVY, A. H. Control of oxidative browning and in vitro propagation of Strelitzia reginae. HortScience, Alexandria, v. 18, p. 434-436, 1983. 